\title{
ARRANGED MARRIAGES AND INTERRACIAL LOVE RELATIONSHIPS IN WOMEN'S CINEMA OF THE SOUTH ASIAN DIASPORA
}

\author{
MATRIMONIOS CONCERTADOS Y RELACIONES \\ SENTIMENTALES INTERRACIALES EN EL CINE DE MUJERES \\ DE LA DIÁSPORA SUDASIÁTICA
}

\author{
Jorge DIEGO SÁNCHEZ \\ Universidad Alfonso X El Sabio
}

Received: 08/01/2016

Accepted: 22/06/2016

\begin{abstract}
Gurinder Chadha and Mira Nair's films define diaspora as a diaspora space where women are portrayed as change agents. This paper explores how Chadha and Nair provide a different representation and possibilities for South Asian women in the diaspora in the description of arranged marriages and interracial love relationships so that they present pioneering female characters that subvert orientalist misconceptions about the South Asian Subcontinent and South Asian women. By so doing, this essay confirms how Chadha and Nair's selected films propose new postcolonial models that promote the construction of new roles for female characters in cinema that challenge the racial and gender inequality suffered by women in the United Kingdom, the United States of America and the South Asian Subcontinent.
\end{abstract}

Keywords: South Asian diaspora, arranged marriage, interracial love relationships, cinema.

\section{Resumen}

Las películas de Gurinder Chadha y Mira Nair definen diáspora como un espacio de diáspora en el que las mujeres pueden ser representadas agentes de cambio. Este trabajo estudia la manera en la que Chadha y Nair subvierten concepciones orientalistas sobre el Subcontinente sudasiático y las mujeres sudasiáticas presentando personajes 
femeninos pioneros que luchan contra la desigualdad racial y de género en Reino Unido, Estados Unidos y el Subcontinente Sudasiático desafiando los roles impuestos social y culturalmente respecto a su participación y la representación de los matrimonios concertados y las relaciones sentimentales interraciales. El estudio de la filmografía selecta de Chadha y Nair refleja cómo proponen nuevos modelos postcoloniales que favorecen la creación y acción de personajes femeninos en la diáspora y en el Subcontinente.

Palabras clave: Diáspora sudasiática, matrimonio concertado, relaciones interraciales, cine. 


\section{INTRODUCTION}

Diaspora is a gendered and stereotyped space. Gendered because there is a series of economic, political, cultural and social burdens imposed on women that act, as Bell Hooks recognises, as interlocking systems of domination over women based on sex, gender and class (21). Stereotyped because there are reductionist and essentialist representations about South Asian culture in diaspora as seen, for instance, in Nicole Kidman Hindu bride's apparel in Baz Lhurman's Moulin Rouge (2001) or London based Department Stores Harvey Nichols's displaying windows in the summer of 2002 (decorated following the arrangements of a Punjabi wedding). According to these examples, there has been an Orientalising representation of the South Asian weddings and love relationships promoting the «fastuosity [...] of an exotic tradition» (Lewis 12) where both women and South Asian cultural elements are portrayed as stereotypical traits to be looked at from a distance.

It is important to review the discourse made by artists from the South Asian Subcontinent in the homelands and in diaspora to recognise that, for example, weddings and interracial love relationships emerge as alliterative tropes of the cultural negotiation among the homelands, the diasporic resultant cultural hybridity and the consequent conflicts that are inherent to the South Asian distinctiveness and its diaspora. The commitment of this article is that of analysing the similar representational situations in a selection of films by South Asian filmmakers in the diaspora Gurinder Chadha and Mira Nair to examine much more explicitly these conflicts of gender inequality.

The methodology followed responds to Gender, Postcolonial and Cultural studies. Thence, variables of domination according to gender, race and cultural representation in the cinema will be considered to describe which reality Chadha and Nair represent in their films, if it corresponds to the real one and, most important, what is new in their features in terms of representation and opportunities for South Asian women in the diaspora. Accordingly, patriarchal structures of family control, racist patterns of inequality in the freedom to choose love patterns and chauvinist socio-political structures in the diaspora will be taken into account in the selected films to elucidate what 
makes Chadha and Nair's films add pioneering details and proposals in the description of women in the diaspora.

Gurinder Chadha was born in Nairobi (1960, Kenya) and, as an East African Indian descendant, diaspora has troubled her life in the most enriching ways. The Chadhas emigrated to British Kenya from the Punjab as a Sikh family looking for a better economic prospect: the father as a banker and the mother as a shop tender. Hardly was Gurinder Chadha two years old, when her family moved to Southall, England. In the UK, she would be brought up as a British girl surrounded by the peculiarities of the South Asian cultures from the East African Indian diaspora. During her last two years at high school, Chadha recognised the racism imposed by the British white-normativity when, at the times of her Leaving Certificate Exam, she was appointed «to do [her] best and become a hard working secretary» (Chadha 2). Nevertheless, her family's historical spirit of struggle encouraged her to prove her teachers wrong and strengthen her own sense of independence (Chadha 2).

During her first year at East Anglia University (United Kingdom) she would see a photograph of a black man wounded during the 1980s Brixton riots under the headline «The Future of Britain» (Chadha 1). At that point, she decided to turn herself to cinema and illustrate her own vision for the future of Britain (Chadha 1). Later, Chadha would start to work for BBC Radio and she gathered enough artistic and economic support to shoot her first feature, the short film I'm British but... (1990) and then Bhaji on the Beach (1993) where she researched and portrayed, respectively, the emerging importance of the bhangra music in the making of the incipient South Asian identity in the United Kingdom as well as the gender and racist problems faced by first generation South Asian girls living and studying in the UK. After, Chadha founded her own producing company, Umbi films, and she started to grant international recognition and worked to create one of the most important films in 2002, Bend It like Beckham which earned her international and economic success.

Mira Nair is illustrative of the diversity of the South Asian diaspora in the UK and in the US. Nair was born in Punjab but soon emigrated to the Orissa Province, then to Delhi and afterwards to the US, Uganda and South Africa. After graduating from Delhi University, where she administered her own amateur theatre company of theatre (where she also acted), Nair obtained a scholarship to study Drama at University of Harvard and learned a new way of directing and performing theatre from British director Peter Brook and his disciples (Nair 3'40"). This experience was «an opening of horizons» that let Mira Nair realise that there were two kinds of theatre: one that was kind 
and «too conventional» as opposed to other that gathered «the bustle of the Indian streets stages, so [she] soon turned [herself] to cinema, and it empowered [her]» (Nuir 26).

After shooting documentaries about social inequalities in India, she co-wrote with Harvard College Indian friend screenplay writer Sooni Taraporevala the draft of Salaam Bombay (1988). The resultant project met a tremendous international success (Cannes Film festival's 1989 Palme d'Or and nominations for Best Foreign Feature at the 1989 Oscars and BAFTAs). Later, she directed Mississippi Masala (1990) and founded her own producing company, Mirabai Films. This is a very remarkable fact because, together with Chadha's establishment of Umbi Films, there were two non-white, immigrant women starting to subvert the previous limiting economic and creative structures in the early 1990s. Nair's next features continued dealing with the themes of displaced people (The Perez Family, 1995, and My Own Country, 1998) and the social inequalities applied to race, class and gender (Kamasutra: A Tale of Love, 1996, and The Laughing Club of India, 1999). After these films, Mira Nair would astonish the world with the diasporic Punjabi wedding portrayed in Monsoon Wedding (2001), the film that won Golden Lion at the Venice Film Festival in 2001. Furthermore, in 2006, she would undertake the cinematographic adaptation of the novel The Namesake (2003), written by her Bengali American friend Jhumpa Lahiri, which received very positive reviews.

Thus, Gurinder Chadha and Mira Nair are the perfect representatives of the plurality of the South Asian diaspora and, similarly, their films are inspiring conceptualizations of the hybrid postcolonial societies in different nations across the globe. Moreover, they offer in their films an idiosyncratic South Asian illustration of the gender conflicts that can be seen in the motifs of the wedding and the love interracial relationship in both the homelands and the diaspora so as to evaluate the encounter between racial differences and the subaltern position that, both individually and socially, is still occupied by South Asian women in the diaspora.

\section{SOUTH ASIAN WOMEN IN THE DIASPORA SPACE: GURINDER CHADHA AND MIRA NAIR DIASPORIC FILMS}

Nowadays, themes of belonging, identity and national citizenship alongside the relation of the migratory movements obviate the recurrent human necessities of the displaced person. As it has been stated elsewhere (Diego Sánchez, 2010, 2015), the resultant coexistence of new and complex identities consequently requires a theoretical definition that helps analyse the contact among the many different cultures in motion, a contact revealed as a 
multisided composite in the context of the South Asian Subcontinent and its diaspora. It is from this conjectural crossroads that diaspora is understood as a diaspora space, where the union of cultural, political and economic factors is performed as a postcolonial outcome.

Under these postcolonial proclaims, diaspora, as a theoretical term, displays the top of an iceberg that usually only addresses the arrival and departure of people linked to migration, ignoring the undergoing processes of cultural coexistence and mutual influence. The Greek etymology of the word would therefore denote the peak of the iceberg, since dia means «through» and sperein «to scatter». It was in this sense that the first use of the term diaspora referred to the scatterings of people of the first Jewish diaspora ( $1^{\text {st }}$ century $\mathrm{AD}$ ). Robin Cohen recognises that the common features shared by any contemporary diaspora with the ancient Jewish diaspora point at ethnographic consequences such as «an expansion from a homeland in search of work, in pursuit of trade or the further colonial ambitions», «a collective memory and myth about the homeland, including its locations, history and achievements» or «an idealization of the putative ancestral home, and a collective commitment to its maintenance, restoration, safety and prosperity» (26). Nevertheless, Cohen acquaints the submerged part of the iceberg when he points out that «diaspora unveils a hidden possibility of a distinctive creative $[s i c]$ which enriches life in host countries with, among all cultural grandiosities, a tolerance for pluralism» (26). It is here that the underwater interstice of diaspora is revealed as a powerful process of identity making, determined by cultural contact and enriching conflict.

Therefore, diaspora involves a process of transformation that goes beyond the dispersal of peoples. Diaspora becomes a multiple passage, what Paul Gilroy defines as the collision between «roots and routes» (34), the dilemma shared between the «locations of residence» and the «locations of the belonging» (36) which creates a particular constant reformulation. This space of convergence is what Steven Vertoveck calls «the diasporic mode of cultural production» $(2000,199 ; 2009,24)$. Here, diaspora is a conceptual, agglutinating site of immanence defined by Brah as follows:

[The] concept of diaspora should be understood as an ensemble of investigative technologies for genealogical analysis of the relationality within and between different diasporic formations. The potential usefulness of the concept of the diaspora today rests largely upon the degree to which it can deal with the problematics of the late $20^{\text {th }}$ century transnational movements of people, capital, commodities, technologies, information and cultural forms. I have also suggested that the concept of 'diaspora' articulates with that of 'border'- the latter is concerned with the construction and methaporisation of 
territorial, political, cultural, economic and psychic borders. In these various forms, borders are social constructions with everyday effects in real lives. I have argued that the concepts of 'diaspora', 'border' and the 'politics of location' are immanent. I define this site of immanence as Diaspora Space. (241, my emphasis)

Diaspora space thence addresses the distinctiveness of both the top and underwater figurative iceberg. Diaspora also unveils a multiple journey beyond spatial terms, a composite of identities, differences and border-crossings which are reciprocally self-constituting. In this sense, culture in the diaspora space must be understood in reference to what James Clifford defines as «a site of travel» (199), pointing at the constant interconnection Ania Loomba categorises as «the intersection of the multiple histories and stories of postcolonialism and colonialism» (183). For this reason, diaspora space is a collaborative cartography for our contemporary age, the system framing what Bhabha defined as the «moment of transit where space and time produce complex figures... reminding us that history is happening» $(1,25)$. It is at this place that the cultural intercourse that takes place in the diaspora space unveils the interconnection of the diverse experiences that defines culture as a complex hybridised phenomenon.

Diaspora space is therefore the abstract space where cultures and identities are situated in the context of border meddling, where cultures share a process of mutual, symbiotic influence. In this sense, if Brah's diaspora space is a «composite formation» (196) then hybridity is the composed result. Respectively, Ella Shohat remarks:

[Hybridity] assures the negotiation of the multiplicity of identities and subject positioning which result from displacements, immigration and exiles without policing the borders of identity along essentialist and originary [sic] lines... hybridity guarantees the non-universalising, neo-colonial perspectives. (329)

Accordingly, hybridity responds to what Ashcroft, Griffiths y Tiffin call the «postcolonial process of resistance and reconstruction»(2), in the same line as Indian anthropologist Akhil Gupta states that «the recognition of cultural hybridity gives voice to the ever-present subaltern struggle» (qtd. in Spivak 76).

Thus, hybrid identities are contesting identities that are produced in the diaspora space combining traces from the past as well as from the emergent cultural components of the present-future moment. This is the suggestion of a heterogonous negotiation of cultures proposed by works such as Ahmed 
(2012, 2014); Ali, Kalra and Sayyd; Bhati; Brown; Kumar Sahoo and Sheffer; Van der Veer; Wilson.

Accordingly, only by acknowledging the hybrid identities formed in the South Asian diaspora space can characters like Ashima in Mira Nair's The Namesake (2006) or Asha in Gurinder Chadha's Bhaji on the Beach (1993) be understood. These characters are women who live in Avtar Brah's conception of the diaspora space as the abstract space of convergence between «specificities» (economic, political, cultural variables) and «modalities» (such as gender, race, class and religion) where the hybridity of cultures is produced (24-5). It is from this perspective the transcultural contact performed at this diaspora space will be illustrated as a space that leads to the construction of a hybrid identity that articulates the contemporary diversity of cultures beyond static discourses such as those of multiculturalism ${ }^{1}$. The distinctive particularities of the post-Partition (1947 onwards) South Asian diaspora will then prove the relevance of the discourse.

Thereby, the concept of diaspora space perfectly illustrates both the coexistence of many cultural layers and influences shared by the Indian Palimpsest and the South Asian diaspora. It is then by recognising the hybridity of the South Asian Diaspora that the «diasporic Indian plurality» (Raghuram, Kumar Sahoo 1) and the "complex identifications from where the Indian diaspora emerges» (Moorti 358). It is in this abstract space that, as Avtar Brah recognises, modalities and specificities encounter each other and produce (and reproduce) diasporic identities. And these diasporic identities redesign new horizons that had imposed limits and burdens based, predominantly, on the gender modality.

Having contextualised the critical and methodological approach of the following pages, it is time to explain the selection of movies directed by Gurinder Chadha and Mira Nair that will be referred as diasporic films. These features have been chosen because they portray the postcolonial experiences of the characters as direct consequence of the constant cultural interaction and social connection among the UK and the US and the South Asian Subcontinent. Similarly, these films provide an all-inclusive account of the South Asian diaspora because they are solely based on the transcultural conflicts that, in terms of race and gender, are encountered by the hybrid identities represented. It is in this sense that Chadha's Bhaji on the Beach (1993) and Bend

1. The term multiculturalism unveils a restrictive acknowledgement of the diversity of cultures. Besides, it does not provide a space to study the discriminatory and racist conflicts that emerge in the vertical relationship of cultures promoted by the multicultural speech. 
It like Beckham (2002) will be dealt with as representative of the South Asian diaspora and first/second generation born in the UK; Mira Nair's Mississippi Masala (1991) and The Namesake (2006) as illustrative of the same reality in the US context; and Gurinder Chadha's Bride and Prejudice (2004) and Mira Nair's Monsoon Wedding (2001) as exemplary of how the South Asian diaspora in the UK and the US reciprocally connects back with the Subcontinent.

Weddings and love relationships in the diaspora are alliterative representational tropes of the cultural negotiation between the diaspora space's resultant hybridity and the consequent conflicts that are inherent to the South Asian diasporic distinctiveness. It is also remarkable that the depiction of the rituals always underlies a gender conflict where the South Asian female migrant occupies a subaltern position, both under the domination of the white and the South Asian male yoke. These similar representational situations in the selected films by Gurinder Chadha and Mira Nair are key to examine much more explicitly these conflicts of gender inequality.

Gurinder Chadha and Mira Nair use the tropes of the wedding ceremony and the interracial love relationship as examples of hybrid constructions in diaspora space with the aim of examining much more explicitly gender inequality in the diaspora space. Likewise, representational situations of arranged/love marriages by focusing on the characters of Namita in Mira Nair's Mississippi Masala (1991), Aditi in Nair's Monsoon Wedding (2001) and Ashima in Nair's The Namesake (2006) are analysed in the following section. Later, gender inequality associated to the interracial relationships between Mina and Demetrius in Nair's Mississippi Masala and Hashida and Oliver in Gurinder Chadha's Bhaji on the Beach (1993) will be evaluated with the purpose of unveiling the hybrid possibility that is granted by the performance of the diaspora space's transcultural coexistence.

\subsection{Weddings in the diaspora}

Gurinder Chadha and Mira Nair's chosen films (but for Bhaji on the Beach) all portray a South Asian wedding in the diaspora. The statement is extensive to other films like those by Pratibha Parmar and Indian Canadian Deepa Mehta. So, representational situations of arranged/love marriages in the selected feature will be studied by focusing on the characters of Namita in Mira Nair's Mississippi Masala (1991) and Aditi in Nair's Monsoon Wedding (2001) and Ashima in Nair's The Namesake (2006). Secondly, gender inequality will be described by the interracial relationships between Mina and Demetrius in Nair's Mississippi Masala and Hashida and Oliver in Gurinder Chadha's Bhaji on the Beach (1993) to exemplify the hybrid possibility that is granted 
by the performance of the diaspora space's transcultural coexistence of their relationship.

To start with, there is no doubt that the traditional notion of marriage in the many South Asian cultures (whereas following Hindu, Muslim Sikh or Jain rituals) is a social scheme controlled by men, as expressed by French feminist Luce Irigaray's definition of marriage as «a system of exchange organized by patriarchal societies... modalities of productive work that are recognised, valued and rewarded in these societies as men's business» (174). In this regard, the notion is that a man can choose among a variety of potential options, meaning that a woman must wait to be chosen for she has no possibility to arrange a future for herself. Nazneen, the main character in Monica Ali's novel Brick Lane (2002) illustrates the trend when she asserts: «[My] fate does not belong to myself. It is [my husband's], it is my family's and it is God's» (4). Similarly, US anthropologist Lewis Hyde defines the general submissive position sketched for the wife as: "[The] woman who is given in marriage similarly takes on typical functions of the gift. She also establishes a bond (between clans or families), and as a part of an ongoing system of kinship, she, like any gift, becomes an agent of the community's cohesion and stability» (99). The role of the wife is then sketched to fulfil a passive role that keeps patriarchal systems of domination alive that is extensive to the normative Bollywood movies as examined by Sangita Gopal.

The figure of a married South Asian woman thence becomes Orientalised (Said) as a silent and powerless victim, pretty much like in those caricatures offered by British officers in India which, during colonial times, represented all Indian women as Hindu widows eager to jump into a pyre ${ }^{2}$. The contemporary readings of such a stereotypical representation are extensive to the women in the South Asian diaspora, where the migrant wife is portrayed as «only a subject to suffer an izzat crime or a crime of honour» (2000, 26, my emphasis), as recognised by South Asian British feminist Amrit Wilson. In this sense, Wilson continues: «I have argued that the State [and media]... interventions have in general strengthened South Asian patriarchal relations» (2000, 95). Wilson's remark (2000) clearly summarises the essentialist representation normally sketched for the South Asian diasporic woman also as

2. Indian scholar Santosh Singh describes why the Hindu widow had to undertake sati (the jumping of the widow into the pyre as following her husband's death) as told by the Upanishads. In his own words: «[A] woman, unable to bear the pangs of separating from her deceased husband, considers her life futile without him, ends her life... to perform every form of penance and atonement for the sins committed by her which had caused her husband's death and made her a widow» (12). 
a passive victim. It is exactly from this point that the depiction provided by Chadha and Nair about arranged marriages is based on the possibility of subverting the presupposed submissive role of the bride and the limiting Western evaluation given to the Eastern cultural tradition.

Respectively, the selected films show arranged marriages that make a possible subversive choice for characters like Namita in Nair's Mississippi Masala (1991), Aditi in Nair's Monsoon Wedding (2001) and Ashima in Nair's The Namesake (2006). Subversion here means transformation towards the recognition of the idea that a woman's fate should be only of her own as well as the acknowledgement that the diaspora space empowers the option that another reality is always achievable.

Likewise, Namita (the Indian woman whose marriage is arranged to provide some company to Anil, Mina's cousin and the owner of the motel business) refuses to Anil insistence on having sex with her because she realises that he is using her to obtain personal pleasure from where to counteract the stress caused by the litigation started by Demetrius (1h29'03"). Here, and reversing the fact that in the beginning of the film Namita blamed herself for Anil's own sexual impotence, she will turn to laugh at him and reject having sex with him, something that she did not dare to do before. Namita, therefore, subverts her initial description as the submissive wife brought all the way from Jaipur (India) to provide some company and calm to Anil. Now, Namita knows that she is not to be blamed for Anil's sexual incapability. Actually, she is a clear representative of the transformative power that the diaspora space opens for marriage and love relationships, because Namita will later challenge the social and family expectations that had been placed on her as a reaction against the general opinion of the aunties in the South Asian community in Mississippi, as the same gossipers assert in another part of the film: «[All] these proper Indian women are getting too many radical ideas from American women like Mina. We'd better send them back to India» (1hll'). Consequently, not only does Namita awake to the gender restrictions that have been laid upon her but she also embraces a possibility to live for herself through her arranged marriage, as inspired by the path already opened by the much more subversive relationship of Mina with African American Demetrius. Similarly, Aditi in Nair's Monsoon Wedding turns her arranged marriage into a possibility of weaving a future of her own.

Aditi is trapped in a secret affair with Vikram Mehta, one of the most famous TV presenters in India. Aditi continues to see Vikram the days before her arranged marriage ceremony with Hemant Rai, an Indian doctor resident in Houston Texas (US) where they are supposed to settle down after the 
wedding. Nevertheless, on the day before the ceremonies, Aditi and Vikram are discovered by the Police in Vikram's car in a rather indecent pose (1h02'05"). The Police soon recognise Vikram's face and Aditis hands, painted in henna as a symbol of the incipient wedding. Alarmed by the great offence they are committing (no sexual intercourse is allowed before the Hindu marriage is performed), Vikram leaves Aditi out of the car because his wife has phoned him and he needs to make up an alibi. In the meantime, Aditi gets insulted by some of the officers. Vikram keeps talking to his wife and pays no attention whatsoever to the assault they are infringing on Aditi. Aditi looks at Vikram, and kicking the policemen, understands that Vikram has been using her as a mere mistress. After such a paradigmatic incident, she steals Vikram's car and she arrives back at her home with the firm intention of confessing the love affair to her fiancée Hemant. So, she tells him all about her secret affair (1h14'37"-1h15'10"). At that point, Aditi chooses to speak for herself and so she reconciles with her inner self. This is the moment where she thinks about the arranged marriage in terms of a "suggested date» (58'), as she will afterwards tell Ria, adding that the marriage will open a new possibility where she will be herself (1h14'59").

Subsequently, Mira Nair sketches the concept of arranged marriage far from victimising and stereotyping representations of the South Asian woman. Instead, Nair depicts the arranged marriages as a tradition that does not have to be derogative as compared to the West's traditional notions. Accordingly, Nair depicts how Aditi accepts the arranged marriage as a completely valid option that is part of their traditional culture. The same happens with Moushumi (in Nair's The Namesake) who, as a successful independent woman, accepts the arranged dates with Gogol and ends up marrying him to later get the divorce. For this reason, Nair dismantles the stereotypical Western discourse laid upon arranged marriages as a prison for the South Asian woman and reinforces the idea that, depending on the way the marriage proposal is designed, the woman has an option to decide for herself. In this sense, Namita and Aditi recognise the gender burdens imposed on them and come to terms with the possibility of subversion inherent to the acknowledgement of their socio-economic possibilities as women of the world, the woman without borders that the paradigmatic character of Ashima represents in Nair's The Namesake. Thence, by demystifying the notions circumscribed to the arranged marriage, Mira Nair succeeds in representing these three women as performers of a new path that opens up from the diaspora space. 


\subsection{Interracial Relationships in the diaspora}

It is at this point that the convergent study of both Chadha and Nair's diasporic films provides a much more insightful analysis of the South Asian distinctiveness because, besides proposing the possibility of an active role for South Asian female characters, they also enhance a stronger reading of the current transnational dynamics by means of presenting interracial love relationships that evaluate the transcultural environment and the diversity of us all citizens of the contemporary world. Here, Chadha and Nair offer two kinds of interracial relationships in the selected movies. On the one hand, there is the usual dichotomy that defines the relationship between a white man and a South Asian woman with a two-fold representation. Firstly, a successful, rich white man appreciated by the South Asian family as a good match and a South Asian woman who is rejected by the white family considering that it is not a proper option in terms of economic status (as in the case of Lalita and $\mathrm{Mr}$ Darcy in Chadha's Bride and Prejudice). Secondly, a white man of low social status rejected by the South Asian family, as the relationship between Punjabi Jess and Irish Joe shown in Chadha's Bend It like Beckham ${ }^{3}$. On the other hand, the paradigmatic affair between a black man and a South Asian girl, an interracial breakthrough cinematographic portrayal opened up by both Nair's Mississippi Masala and Chadha's Bhaji on the Beach in the early 1990s. However, the different prospects for a love relationship describe a gender burden placed on the South Asian woman: she is either to submit to family expectations and cultural prospects or to subvert them according to her own will. Thus, Chadha and Nair propose female characters that choose the second option and, by so doing, they empower the transformation of the South Asian woman and her possibilities within the context of the hybridity of cultures, as illustrated by Mina and her interracial relationship with Demetrius in Nair's Mississippi Masala (1991).

Significantly enough, this was the plot line from which Bell Hooks and Anuradha Dingaway addressed Mississippi Masala as a film that offered «only stereotypical portraits of Southern whites and blacks» (42). This was a truly essentialist analysis that clearly ignored the interplay of interracial mediations suggested by Nair and screenplay writer Sooni Taraporevala at the moment the film was released. Actually, Hooks and Dingaway's review obviates the

3. A third option could be subject of study in a further academic research, that of the rich white family that finds exotic to meet other cultures and so approves of their children having a relationship with a migrant, although always under that Orientalist raison d'être, as seen in the affair between Gogol-Maxine in Nair's The Namesake. 
interracial alternative proposed by Mina and Demetrius' relationship, as the unconventional model that, in the US and in the early 1990s, Nair proposed to represent the existent problematic of race, colour and identity. In fact, this interracial relationship between a woman of an Indian background and an African American self-made man (Demetrius runs his own Cleaning Services business) works as a common space both built and shared by Mina and Demetrius to undertake a double-fold evaluation: the negotiation of postcolonial identities in the diaspora and the subaltern position held by the migrant woman, as Mina must cope with the social and family expectations that are imposed upon her.

In this sense, Mina, as an Indian woman who has never been to India, thinks about her hybrid identity as a masala experience (masala is a combination of different species without following any specific amount) and realises that she shares a common history with African Americans, as both Tyron and Williben explain to Demetrius' grandfather at his birthday lunch:

[Mina] is just like us. We are from Africa but we have never been there, although there is where our loyalty and love is. Well, although she was born in Africa.... [Well], black, brown, yellow, at least you are no white. (53'47"-53'51")

After the pleasant meal, both Mina and Demetrius go for a walk along the beach and they talk about how race has undetermined their opportunities. Mina complains about how «many people come to the motel, look at us and say to us, ugh, another damn Indian» (1h06'02") and Demetrius assumes that «being black, I have achieved all I could ever long for: my own cleaning service enterprise, although all dependant on a white's loyalty loan» (1h06'29"). Nevertheless, as they stroll together in this emblematic liminal space, race is not a burden for them, as Demetrius tells Mina: «Well, Miss Masala, race, or as they say now, tradition, is passed down like recipes. The trick is to know what to eat and to leave on the plate», to which Mina answers: "[Otherwise], we will be hungry for ever» (1h06'33"-1h06'52"). However, race is a burden for Mina's family, as they still believe that they do not belong to the same social strata as Demetrius because, for them, Indians are above African Americans, an idea inherited from the Indenture system that backed from the colonial times.

It is here that the interracial relationship between Demetrius and Mina embraces the possibilities of the diaspora space, because they can enjoy a life only dependant on themselves and so Mina will be able to have an education of her own far from the Motel business ran by Mina's family. Together, both Mina and Demetrius illustrate the transformative possibilities of the cultural 
hybrid identity, as Mina recognises her roots and the new possible routes that lay ahead of her by acknowledging that she is «a mixed masala... a bunch of different spiced mixed up together» (47'43"). Then, Mina would say to her family after she has been arrested for insulting a white policeman back: «This is America. [Now] I am in America and no one cares» (1h17"). Moreover, she has in mind this idea when she informs her parents that she is running away with Demetrius because they are going to start a business together, somehow stating that she cannot go to Uganda with her family because she now lives in the US and Jay and the South Asian community keep stuck to the recipe of racism that previously constrained Mina's life because Jay is reluctant to see beyond the opposition of races (1h40'42"-1h4l'58").

It is only after Mina's runs away with Demetrius to start their subversively interracial relationship that her father Jay feels the necessity to go back to Uganda and question what his roots and routes are. It is at that moment that his wife Kinnu enlightens him: «Mina is like you, Jay. She can't grow up [in the motel] anymore. You must go now, you think of Uganda all the time. Go and see for yourself what is like» (1h42'42"). This is the new juncture opened by both Mina and Mira Nair's hybrid cinema, as both refuse presupposed descriptions of a powerlessness woman but they congratulate the possibilities of the masala identity, of the mixture of different spices without a fixed recipe. It is so that Mira Nair presents Mina as a subversive performance and performer of the diaspora space, because she is both an active agent and a result of the new cultural interplay of cultures. The character of Mina acts a point of departure to break away with previous clichéd descriptions sketched for the South Asian migrant woman, a new character constructed beyond static racial distinctions. It is from this challenging portrayal that the final words uttered by Mina to her family reinforce her as a woman without boundaries in an interracial world, as she answers to both Kinnu and Jay when asked to return to the Motel: «I am not going back, I am with Demetrius. I can't. If I don't leave now I never will» (1h40'42"). This is the moment when Mina has finally challenged both the racist and gender burdens imposed on her. She is creating a new route that is to be followed by other women of her community like Namita or her own mother, as well as to any other member of the South Asian social group, as represented with Jay's last decision to go back to Uganda. Furthermore, this is the same path previously referred to when talking about Ashima in Nair's The Namesake (2006) as well as the decisions made by Hashida in Gurinder Chadha's Bhaji on the Beach (1993), where both Chadha and screenwriter Meera Syal also describe an interracial 
love relationship as the means to evaluate the patriarchal and imperial burdens that keep the subaltern position of the South Asian migrant woman in the diaspora.

It is important to recall that, as stated in the previous section, Hashida feels imprisoned between her family and community's expectations of becoming a «triumphant doctor» (9'56") although what Hashida truly wants to study is Arts. Alongside her creative aspirations, Hashida has an interracial relationship with Oliver, an African Caribbean man born in Jamaica who already studies Art at college in Birmingham. Only Manjit (the head of the Saheli Group, the Non-Governmental Organisation for the welfare of the South Asian Women in the Diaspora that organises the trip to Blackpool) knows about Hashida's true educational interests and love affair and so Hashida turns to her seeking comfort when, early that morning, she phones Oliver and ends up arguing because, as Oliver tells her:

«[You] depend too much on your community, for fuck's sake, do what you want with your life.... You are gonna [sic] give up Art like you've given up everything else. Look at you. You are always playing the perfect bloody daughter,.. you don't want hassle» (9').

What Oliver ignores is that Hashida has just discovered that she is pregnant and that if she cannot tell her family what she truly wants to study, it is very difficult that they will understand that her baby will be the child of a black man.

This is the feeling that makes Hashida run to meet Manjit and join the day-trip to Blackpool «to have a little bit of free atmosphere, far from that family of yours» (15'46"), as told by Manjit. On the bus, Hashida receives the good looks from the South Asian women who all say about her (16'). Within the South Asian community, Hashida holds the role of the good and obedient Indian woman as opposed to Ginder who, as previously said, left her husband and his family because he hit her, a fact ignored by all the aunties who blame Ginder for «breaking the peace and honour of the family» (19'21"). Ginder is accompanied during the trip by her son Amrik, and it is significant that Hashida decides to sit with them as opposed to the rest of the aunties, who are only gossiping and criticising Ginder's lack of honour. It is in this sense that when all are sat waiting for Manjit to start the journey to Blackpool, Auntie Pushpa, the oldest of the group, states in a loud voice:

[At] least some of our girls we can be proud of, yes Dr Hashida, she is a credit... Shall we warn Hashida not to talk too much to her [pointing at Ginder]? She might teach her bad habits. You know? She ran off, left her 
family, took her son, even though she had chosen the husband herself. And she has brought the British courts in. (19'22")

She had been earlier interrupted by Manjit who greets them in their different South Asian languages, therefore acknowledging the diversity of the group, and defines what the true meaning for this day out in Blackpool means:

Hello sisters, namaste [Hindi], sat sri akal [Punjabi], salaam a lekum [Arabic]. It's not often that we women get away from the patriarchal demands made on us in our daily lives, struggling between the double yoke of racism and sexism that we bear. This is your day. (16'01'-16'24", my emphasis)

After these welcoming words, it is noteworthy that Ginder says to Hashida, as if she was echoing Manjit's message: "So they say you are going to be a doctor. I gave up college to get married. You are not going to be that stupid» (19'23"). Hashida looks absent-minded at Amrik and asks Ginder, clearly wondering about herself and her recently discovered pregnancy: "How are you gonna [sic] manage, bringing him up on your own», to what Ginder answers: «I've done so far... supposing I'd put up and shut up I'll be more popular though». And Hashida adds: "Yeah, it's so hard knowing what's right any more [sic]. Look, you'll never please everyone, so please yourself» (19'25"). After these words, Hashida is depicted as lost in thought, probably wondering about her pregnancy and getting herself ready to later phone Oliver to inform him that she cannot cope with the reaction that her family and community will bear against her when, besides the pregnancy, she tells that she expects the baby of a black man. Ladhu and Madhu, two women on the trip, listen to Hashida's conversation and they soon tell the aunties who, above all, mostly despise the idea of Hashida seeing a black man and the impossibility of becoming a South Asian doctor if she bears «the child of a black man», as Bina and Pushpa exclaim (41'50").

It is at this moment that Gurinder Chadha explores the double subaltern position occupied by Hashida who, on the one hand, is dominated by the British society that spits and insults the Saheli bus when they stop at the gas-station and, on the other, by the South Asian community that imposes her with an education and a possibility of future only within the South Asian community. Hashida recognises the subaltern position she occupies by means of her repressed desire to be with Oliver, have the child and study Arts. So, she decides to have a coffee to make up her mind, as she informs both Manjit and Ginder (44'35"). A few minutes later, and now within the coffee shop, Hashida listens to the aunties talking about her:

[These] modern girls can't adapt. Those with jobs are worst. My own daughter, I was telling her it's the woman who makes the family. I was teaching 
morals back from home.... Want progress? Like Hashida? She comes from a decent family, still ends up pregnant. Shameless, disrespectful, whore.... Wait nine months then you see how many aunties you have left. Black? Hai Ram ${ }^{4}$, now chaos has come! That will kill your family. (44'37")

At that moment, Hashida stands up for herself, both in action and in metaphor, and throws the boiling coffee to the aunties saying: «You are not my fucking sisters» (44'37'). In other words, she speaks aloud that she is not part of the old static traditions of the South Asian community that constrain the role of women and that she is to lead a life where she can choose what she truly desires. She then runs to the Blackpool Museum and Academy of Arts (which significantly displays an exhibition entitled Race and Britain), sits down and mumbles to herself: «I'm on my own now. I'm in control» (44'52"). It is at this significant moment that Hashida definitely resolves her subaltern position, discerning both the British and South Asian structures that impose her to reject the man she is in love with. Hashida then makes sense of those gender and racial norms both Ginder and Manjit, respectively, have been talking about during the trip. She looks at the portrait she drew of Oliver and, correspondingly, Oliver enters the room. He states: «I am here with you, we will do what you want» (1h17'40"). At this stage, Hashida recognises that she is a woman set only to live her life for herself, as Ginder told her on the bus journey (19'25").

It is so that Hashida realises about the subverting possibilities inherent to the diaspora space as illustrated by the fact that, on the one hand, Hashida can do in the United Kingdom what she truly wants, without any cultural domination and, on the other, Blackpool is celebrating the hybridity of cultures in diaspora through the lighting of Dwivali, and the city looks like any other South Asian or British city. Therefore, Hashida has come to terms with her hybrid identity and, embracing the dynamics of the diaspora space, repossesses her own future where she will live, paraphrasing Mina from Mississippi Masala (1991), as a mixed masala (47'31").

Meanwhile, and parallel to the climax to the story of Hashida and Oliver, the South Asian aunties discover, at the scene in the striptease club, that Ginder was mistreated in her connivance with her husband Ranjit, who threatens her at the door of the pub. At this moment, all of them help Ginder and so Ranjit literally has to run away to escape from the violent and powerful reaction of the all-female group. After this climax and with a feeling of victory, all the women on the trip get on the bus to see the Dwivali lightings along

4. Hindi for «Oh God». 
Blackpool's main street as the same time as they discover Hashida and Oliver hugging each other while admiring the lightings. It is at this moment that all of them wave to Hashida and smile. They all have definitely performed the recognition of their subaltern position and the possibility of interweaving a new collaborative space for women from where to promote their final empowerment as equal participants of the world.

\section{CONCLUSION}

By means of recognising the empathy shared in this new space built in the diaspora, these characters are empowered and so they become empowering women of the world because both Gurinder Chadha and Mira Nair's selected films unveil the patriarchal control imposed by the South Asian community together with the racist attitude showed by the UK and the US structure. By so doing, characters like Mina, Hashida, Aditi, Ashima or Namita challenge these interlocking systems of domination from the possibilities opened by the connivance of cultures that define the diaspora space.

Gurinder Chadha and Mira Nair use the image of the South Asian wedding and the interracial relationship as an original discourse that subverts the South Asian limitation for women to choose their husbands and the Western tokenistic interpretation of, for instance, the notion of the South Asian arranged marriage. Accordingly, Chadha and Nair depict the diaspora space as still ruled by racist and sexist principles but with an intrinsic possibility of subversion. Here, Nair and Chadha's selected films offer a different cinematographic representation because they describe their female characters as weavers of a new common all-female space where they identify their common possibilities and understand each other's roots and routes. Thence, the resultant collaborative space is born out of the transformative role inherent to the diaspora space where women nurture each other towards the empowerment of the South Asian women in the diaspora that departs from a mutual subversive hope that allows them to definitely talk back.

\section{REFERENCED WORKS}

Ahmed, Sarah. On Being Included: Racism and Diversity in Institutional Life. Durham (NC, USA): Duke Press, 2012.

Ahmed, Sarah. Willful Subjects. Durham (NC, USA): Duke Press, 2014.

Ali, Monica. Brick Lane. London: Harper Collins, 2002.

Ali, Nasreen, Virinder S. Kalra and Siddiq Sayyd. A Postcolonial People. South Asians in Britain. London: Hurst \& Company, 2004. 
Ashcroft, Bill, Garreth Griffiths and Helen Tiffin (Eds.). Post Colonial Studies. The Key Concepts. London: Routledge, 2000.

Bhabha, Homi K. The Location of Culture. London: Routledge, 1994.

Bhati, Sunil. American Karma: Race, Culture, and Identity in the Indian Diaspora. New York: New York University Press, 2007.

Brah, Avtar. Cartographies of Diaspora. Contesting Identities. New York \& London: Routledge, 1996.

Brown, Judith M. Global South Asians. Introducing the Modern Diaspora. London: Cambridge University Press, 2006.

Chadha, Gurinder. «A Self Interview with Gurinder Chadha». The Guardian, 16 July 2006. <https://www.theguardian.com/film/2006/jul/16/features. reviewl>, visited 12/01/2016.

Clifford, James. «Travelling Cultures». Cultural Studies. Eds. Lawrence Grossberg, Cary Nelson and Paula Treichler. New York: Routledge, 1992, 68-84.

Cohen, Robin. Global Diasporas: An Introduction. London: Routledge, 1997.

Diego Sánchez, Jorge. «Hybrid Cinemas and Narratives: Gender Representations in Women's Cinema of the South Asian Diaspora». Universidad de Salamanca, 2015. <http://gredos.usal.es/jspui/handle/10366/128136>, visited 8/01/2016.

Diego Sánchez, Jorge. Hybrid Cinemas and Gender Representation in the South Asian Diaspora: The Films of Gurinder Chadha and Mira Nair (MPhil Thesis). Salamanca: Universidad de Salamanca, 2010.

Gilroy, Paul. Between Camps: Nations, Cultures and the Allure of Race. London: Allen Lane, 2000.

Gopal, Sangita. Conjugations: marriage and Form in New Bollywood Cinema. Chicago: University of Chicago Press, 2012.

Hooks, Bell. Ain't I a Woman. Black Women and Feminism. Boston: South End Press, 1981.

Hooks, Bell and Anuradha Dingaway. «Mississippi Masala». MM Z Magazine (July August) (1992): 41-43.

Hyde, Lewis. The Gift: Imagination and the Erotic Life of Property. London: Vintage, 1999.

Irigaray, Luce. «Women on the Market». The Logic of the Gift: Toward an Ethic of Generosity. Ed. Alan D. Schrift. New York: Routledge, 1999, 174-189.

Kapur, Manju. Difficult Daughters. New York: Faber \& Faber, 1999.

Kumar Sahoo, Ajaya and Gabriel Sheffer. Diaspora and Identity in South Asian Diaspora. London: Routledge, 2015.

Lewis, Reina. Gendering Orientalism: Race, Feminity and Representation. London: Routledge, 1996.

Loomba, Ania. Colonialism/Postcolonialism. New York \& London: Routledge, 1996. 
Moorti, Sujata. «Desperately Seeking an Identity. Diasporic Cinema and the Articulation of Transnational Kinship». International Journal of Cultural Studies 6.3 (2003): 355-376.

Nair, Mira. «Mira Nair: National Arts and Humanities Medals Keynote». Ceremony for the National Endowment for the Arts, 2011. <https://www.youtube. $\mathrm{com} /$ watch?v=2N14y-C-uOY>, visited 22/08/2014.

Nuir, John Kenneth. Mercy in Her Eyes. The Films of Mira Nair. New York: Applause Theatre \& Cinema Books, 2006.

Raghuram, Parvati and Ajaya Kumar Sahoo. «Thinking 'Indian Diaspora' for Our Times». Tracing an Indian Diaspora. Eds. Parvati Raghuram, Ajaya Kumar Sahoo, Brij Maharai and Dave Sangha. New Delhi: SAGE, 2008, 1-20.

Said, Edward. Orientalism. New York: Vintage Books, 1979.

Shohat, Ella. «Notes on the Postcolonial». Contemporary Postcolonial Theory. A Reader. Ed. Padmini Mongia. London: Arnold, 1996, 322-335.

Singh, Santosh. Passion for Flames. Jaipur: RBSA Publishers, 1989.

Spivak, Gayatri Ch. «Ghostwriting». Diacritics 25.2 (1995): 65-84.

Van der Veer, Peter (ed.). Nation and Migration: The Politics of Space in the South Asian Diaspora. Philadelphia: University of Pennsylvania Press, 1995.

Vertoveck, Steven. Transnationalism. London: Routledge, 2009.

Wilson, Amrit. The Hindu Diaspora. Comparative Patterns. London: Routledge, 2000.

Wilson, Amrit. Dreams, Questions, Struggles: South Asian Women in Britain. London: Pluto Books, 2006. 